\title{
Appraisal of the Impact of Earnings Management on Financial Performance of Consumer Goods Firms in Nigeria
}

\author{
Ubesie Madubuko Cyril, Nwankwo Bobby Godwin Ogbogu, Nwankwo Peter Emeka \\ Department of Accountancy, Faculty of Management Sciences, Enugu State University of Science and Technology, Enugu, Nigeria
}

Email address:

ubesiemadubuko@yahoo.com (U. M. Cyril)

\section{To cite this article:}

Ubesie Madubuko Cyril, Nwankwo Bobby Godwin Ogbogu, Nwankwo Peter Emeka. Appraisal of the Impact of Earnings Management on Financial Performance of Consumer Goods Firms in Nigeria. Journal of Finance and Accounting. Vol. 8, No. 1, 2020, pp. 34-47.

doi: $10.11648 /$ j.jfa.20200801.15

Received: January 7, 2020; Accepted: January 18, 2020; Published: February 14, 2020

\begin{abstract}
There are two different tools of earnings management; real activities and accruals. Prior research shows that the discussion on earnings management was primarily focused on accrual manipulation strategies while recently many articles have focused on real activity manipulation as a proxy for earnings management. In accrual manipulation, managers introduce their judgment and subjectivity by accounting choices in the financial reports, and hence it could distort a company's underlying operating performance. The main objective of this study was to determine the impact of Earnings Management on financial performance of consumer goods firms in Nigeria. The study adopted the ex-post facto research design and used simple regression analysis for analysing the pooled secondary data obtained from three selected consumer goods firms in Nigeria. The dependent variable in this study is financial performance proxy by Total Assets, Equity and Total liability of the firms while Earnings Management is the independent variable (proxy by Net profit or Profit for the Year). The findings show that Earnings Management does not have significant impact on financial performance of consumer goods firms in Nigeria. The study recommended that there should be conscious effort by management of consumer goods firms to improve the earnings management situation in order to impact on financial performance of the sector; Management of consumer goods firms should emphasize the equity of firms as a means of widening ownership fund position and internal source of capital; There must be reassessment of the liabilities of such firms for proper positioning of financial performance of consumer goods firms in Nigeria.
\end{abstract}

Keywords: Earnings Management, Financial Performance, Consumer Goods Firms

\section{Introduction}

\subsection{Background of the Study}

There are two different tools of earnings management; real activities and accruals. Prior research shows that the discussion on earnings management was primarily focused on accrual manipulation strategies while recently many articles have focused on real activity manipulation as a proxy for earnings management. In accrual manipulation, managers introduce their judgment and subjectivity by accounting choices in the financial reports, and hence it could distort a company's underlying operating performance. However, it does not generally involve altering operations themselves. In real activity manipulation, on the other hand, managers' objectives are to mislead stakeholders into believing that the results reported in the financial statements have been achieved in the normal course of operations.

Both methods may be used to manage earnings upwards or downwards for several reasons and with different implications for the future of the firm. Real activity is preferred to accrual manipulation because it is easier to implement, less costly and more difficult to detect by outsiders. However, real manipulation is perceived to be less ethical than accrual manipulation, and it can reduce the future valuation of companies as well as their profitability and longterm competitiveness. The decision to opt for one methodology rather than the other can be modified when managers identify circumstances or events whether they need to achieve particular objectives. 
Furthermore, a novel research avenue in earnings management is the investigation of the drivers for the choice of one practice over the other and to explain the reason such as an IPO or financial distress situations. Accounting standard regulators are worried about the implications that both types of earnings management cause to information quality. Furthermore, the consequences originated from earnings management practices have several implications for stakeholders and regulators. Thus, investors and auditors must analyze cautiously the information provided by financial statements which may have been manipulated, while the board of directors and investors should be aware of the opportunistic behaviour that managers can adopt to beat benchmarks [1].

In order to alter their financial results, firms take actions that range from decisions within accounting standards to outright fraud. Decisions made within accounting regulations are often viewed as earnings management and legal practices. This view is based on the acceptability of accounting regulations so that it can draw the line on the continuum distinguishing legitimate earnings management from financial fraud. However, determining whether or when such behavior in the earnings management crosses the line of legitimacy to fraud, in some situations, is not always easy owing to a number of different reasons. The first reason is that earnings management and financial reported fraud, in some cases, share the same elements: for example, they share the same objective, which is to deceive or mislead the users of financial information - both of which are deliberate actions taken by the management to achieve private gains, and both having the potential to cause material loss or damage for the shareholders by relying on false information.

Fraud has the same object as earnings management but differs in terms of earnings management in that fraud is outside of generally accepted accounting principles, whereas earnings management is within GAAP. The fourth reason is that, with many accounting policies, when it comes to application, there is no clear limit beyond which a policy is obviously illegal. For example, expense estimation, may be illegal if the estimated amount is extreme, but legal if it is reasonable and within the spirit of the accounting standards. GAAP does not tell managers specifically what is normal and what is extreme. Levitt's speech indicates that the SEC would target companies that engaged in 'practices that appear to manage earnings', without clearly distinguishing between earnings managed in the ordinary course of business and earnings fraudulently managed in a deliberate attempt to deceive the financial community.

Therefore, in between these extremes are judgments that push the limits of accounting standards and often result in misleading financial results. In this regard, Mulford and Comiskey (2002) refer to such judgments as aggressive accounting [2]. As both earnings management practices and fraudulent accounting can involve intent to deceive, and since the concept of intent is difficult to ascertain for other than perpetrators, the distinction between earnings management and fraud cannot be established through managerial intent alone.

The second reason is that earnings management practices via accounting accruals usually result in financial fraud. When firms inflate reported earnings by using income-increasing accruals, these accruals reverse over time; therefore, firms with income increasing accruals in prior years must either deal with the consequences of the accrual reversals or commit fraud to offset the reversals. The third is that both are driven by the same incentives. Prior research indicates that discretionary accruals components of earnings and cash flow are managed to meet or slightly beat analyst forecasts. Moreover, prior research examines whether or not the same incentives that motivate earnings management similarly motivate fraud, with focus directed towards incentives related to market expectation, debt covenants, and management compensation. In most case identified by SEC, the underlying motivation is managing earnings toward Wall Street's expectations, yet it does not rule out the other incentives [3].

\subsection{Statement of the Problem}

One of the areas of concentration in pursuit of stability and sustainability of the firm is to properly manage earnings of the firm. The changes in statements of accounts such as the statement of position, funds flow statements, statements of operations and performance, etc all lean heavily on earnings management to give true picture of the business. Earnings management is about net profit addition to the profile of the firm.

This important component of the accounting statement is what drives an establishment and helps the management to be more focused in handling assets and liabilities of the firm. The resources of the firm are better put into use when the expectation of increasing the Networth and performance of the firm is the concern of the establishment.

Previous studies have concentrated mostly on manufacturing sector in general. The missing point is that the consumer goods firms have not been examined in specific terms and that is what this study is intended to do.

\subsection{Objectives of the Study}

The broad objective of this study is to assess the impact of earnings management on financial performance of consumer goods firms in Nigeria while the specific objectives are to:

i. Ascertain the impact of earnings management on assets of consumer goods firms in Nigeria.

ii. Determine the impact of earnings management on owners' equity of consumer goods firms in Nigeria.

iii. Verify the impact of earnings management on liability of consumer goods firms in Nigeria.

\subsection{Research Questions}

i. What impact does earnings management have on assets of consumer goods firms in Nigeria?

ii. How does earnings management impact on owners' equity of consumer goods firms in Nigeria? 
iii. What is the impact of earnings management on liabilities of consumer goods firms in Nigeria?

\subsection{Research Hypothesis}

$\mathrm{H}_{1}$ : Earnings management does not have significant impact on assets of consumer goods firms in Nigeria.

$\mathrm{H}_{2}$ : Earnings management does not have significant impact on owners' equity of consumer goods firms in Nigeria.

$\mathrm{H}_{3}$ : Earnings management does not have significant impact on the liabilities of consumer goods firms in Nigeria.

\section{Review of Related Literature}

\subsection{Conceptual Framework}

\subsubsection{Earnings Management}

There are many definitions on earnings management. For example Lev (1989) defines earnings management as earnings (sometimes called the "bottom line" or "net income) that are the single most important item in financial statements [4]. According to Lev, they indicate the extent to which a company has engaged in value-added activities: they are a signal that helps direct resource allocation in capital markets. In fact, the theoretical value of a company's stock is the present value of its future earnings. Earnings are the profits of a company. Investors and analysts look to earnings to determine the attractiveness of a particular stock. Companies with poor earnings prospects will typically have lower share price than those with good prospects. Increased earnings represent an increase in company value, while decreased earnings signal a decrease in that value. Earnings management may also be defined as "reasonable and legal management decision making and reporting intended to achieve stable and predictable financial results."

The accounting information disclosed by companies by way of financial statements is the main way for management to communicate with the various stakeholders who are interested in their economic and financial conditions. This information is taken as in dictators of company performance and is of great importance to those who use it, some of whom include: shareholders measuring management performance; creditors resolving restrictive clauses in debt covenants; clients evaluating a company's ability to supply goods and services; suppliers analyzing whether a company can fulfill its commitments; and employees predicting future outlook and job stability, among others [5].

Earnings management is a form of earnings manipulation that is likely to reduce the reliability of earnings. Firms that engage less in earnings management are likely to offer more permanent accounting earnings. Earnings management is not to be confused with illegal activities to manipulate financial statements and report results that do not reflect economic reality. These types of activities, popularly known as "cooking the books," involve misrepresenting financial results $[6,4]$.

According to Warglien and Sacco (2010) earnings management (EM) is a technique, using which company decision-makers present earning figures in finance statements through managerial judgements based on justification, speculation and, even, deception; they generally carry it out to achieve some individual gains by meeting organizational goals, with the intent to manifest accountability towards the organization and its stakeholders [7]. Thus, three key aspects of EM are: accounting (giving accounts), accountability, and accounting methods (to manage earnings).

Information asymmetry occurs when some parties in business transactions have an information advantage over others [8]. Information asymmetry between managers and external information users allow managers to use their discretion in preparing and reporting accounting information for their own advantage. Although opportunism is limited both by the accounting standards and by independent auditors, there is much recent evidence both in academic literature and the popular press suggesting that managers use their discretion over accounting numbers to achieve private gains. More specifically, this earnings management is an activity where managers use their discretion to mislead stakeholders about the economic performance of the company or to influence contractual outcomes. Because earnings management has the propensity to deceive, it is likely to be difficult to detect. The early studies on the topic tested the connection between managerial incentives and choices of different accounting methods.

Healy and Wahlen (1999) cited in Abbadi and Hijazi (2016) provide a comprehensive definition: "Earnings management occurs when managers use judgment in financial reporting and in structuring transactions to alter financial reports to either mislead some stakeholders about the underlying economic performance of the company or to influence contractual outcomes that depend on reported accounting numbers" [9]. Fischer and Rosensweig (1995) define earnings management as: "Actions by division managers which serve to increase (decrease) current reported earnings of a division without a corresponding increase (decrease) of the long-term economic profitability of the division"[10]. As such, this definition identifies two important components of earnings management: consequences and intent. (Healy \& Wahlen, 1999; Roychowdhury, 2006; Gajevszky, 2014 cited by Abbadi and Hijazi, 2016) argued that the manipulation of accounting figures as an outcome of ordinary operational practices appears to arise from management's motivation to mislead shareholders to ensure that the organization's financial targets have been met in the course of business [9].

Due to the information asymmetry which exists between the company`s insiders and outsiders, individuals within an organization can rely on their control in financial reporting and their access to financial information within the company to overstate the income or to mask obtaining unfavorable results. From this viewpoint, management may use different methods such as hiding the changes in economic performance by creating reserves for future periods, hence reducing income volatility $[11,12]$.

According to Hashim, Salleh and Ariff (2013), earnings 
management practices raise important issue facing the accounting profession [13]. This issue has grown tremendously for the past two decades and continues to be of interest to academics and standard setters. The interests in examining earnings management is grounded in the assumption that this behavior misleads financial statement users and sometimes are precursors of more serious activities such as fraudulent financial reporting. Although many countries have emphasized on the role of good corporate governance practices in reducing the risk of earnings management behavior, it is nevertheless a global phenomenon. Managers are still engaged in earnings management. Despite the importance of this area of research, difficulty in differentiating between management's true belief and management's intent to manipulate earnings remains a challenge for archival empirical research to convincingly document earnings management behavior.

Rahman et al (2013) opined that earnings mean the profits of a company which is represented by the bottom line of the income statement and a summary item in financial statements [14]. Earnings are the vital item in financial statement because it represents to what extent the company engaged in value added activities. Earnings also indicate the signal of direct resource allocation in capital market. Investors and analysts look to earnings to determine the attractiveness of a particular stock. The company's stock is measured by the present value of its future earnings. Companies with poor earnings prospects will typically have lower share prices than those with good prospects. A company's ability to generate profit in the future plays a very important role in determining its stock's price. Since company's value is directly related with future earnings, all the executive needs to understand the effect of their accounting choices or learn to manage earnings so that they can make the best possible decisions for the company.

The extent of real activities manipulation should also vary with the flexibility managers have to undertake such activities. Excess production to absorb fixed costs in inventory is easier to accomplish and more likely to escape detection when a firm traditionally maintains a high stock of inventory. Similarly, a firm with substantial credit sales to dealers can more easily engage in channel stuffing, or accelerating the recognition of sales by shipping goods early to its dealers and booking receivables. The firm possibly has to offer additional price discounts to dealers to compensate them for any additional inventory holding costs.

The accounting information disclosed by companies by way of financial statements is the main way for management to communicate with the various stakeholders who are interested in their economic and financial conditions. This information is taken as indicators of company performance and is of great importance to those who use it, some of whom include: shareholders measuring management performance; creditors resolving restrictive clauses in debt covenants; clients evaluating a company's ability to supply goods and services; suppliers analyzing whether a company can fulfill its commitments; and employees predicting future outlook and job stability, among others.

Therefore, managers, experts in their business, can use their knowledge to disclose information which reflects the economic reality of the company, thus potentially increasing the credibility of financial accounts as a means of communication with those using them. However, managers engaging in the use of their own judgment create opportunities for Earnings Management, in which they make discretionary accounting choices that do not adequately reflect the economic and financial reality of the company.

The use of discretion by managers and their engaging in earnings management derives from the existence of different, but equally accepted, accounting methods used to treat recognition, measurement and disclosure of company economic events. These are not objective but instead depend on managers' judgements and estimations, such as when making bad debt provisions and contingencies, known in academic management literature as accruals. Research has increasingly come to focus, however, on other forms of earnings management, known as operational, in which decisions taken by management have been considered more damaging to companies and market participants because they affect cash flow and not only profit. Moreover, earnings management via accruals is easier for the market, auditors and regulators to detect, compared with earnings management via operating decisions, which could thus encourage companies to use this strategy [15].

\subsubsection{Financial Performance}

According to Kenton (2019) financial performance is "a subjective measure of how well a firm can use assets from its primary mode of business and generate revenues [16]. The term is also used as a general measure of a firm's overall financial health over a given period. Analysts and investors use financial performance to compare similar firms across the same industry or to compare industries or sectors in aggregate. To that extent, there are many ways to measure financial performance, but all measures should be taken in aggregate. Line items, such as revenue from operations, operating income, or cash flow from operations can be used, as well as total unit sales. Furthermore, the analyst or investor may wish to look deeper into financial statements and seek out margin growth rates or any declining debt."

\subsection{Theoretical Framework}

\section{Resource-based Theory}

The study adopted the Resource-based theory which contends that the possession of strategic resources provides an organization with a golden opportunity to develop competitive advantages over its rivals. These competitive advantages in turn can help the organization enjoy strong profits [17].

$\mathrm{RBV}$ is an approach to achieving competitive advantage that emerged in 1980s and 1990s, after the major works published by Wernerfelt, B. ("The Resource-Based View of the Firm"), Prahalad and Hamel ("The Core Competence of The Corporation"), Barney, J. ("Firm resources and sustained 
competitive advantage") and others. The supporters of this view argue that organizations should look inside the company to find the sources of competitive advantage instead of looking at competitive environment for it.

\subsection{Empirical Review}

Rahman, Moniruzzaman and Sharif (2013) studied techniques, motives and controls of earnings management [14]. The authors were of the opinion that earnings are the powerful indicators of the firms' business activities. Since a company's stock is measured by the present value of its future earnings, investors and analysts look to earnings to determine the attractiveness of a particular stock. It was also held that companies with poor earnings prospects will typically have lower share prices than those with good prospects. So, it is believed earnings management plays a key role to determine the share price of a company as well as direct resource allocation in capital market. The paper specially focused on earnings management, quality of earnings and various techniques (like cookie jar reserve, big bath, and big bet) that are used to manage earnings in the business entity. The author suggested that the extent and type of earnings management depends on several factors like stock market incentives, personal incentives, political \& regulatory motives. Finally, the paper concluded that rigorous accounting standard, awareness of audit committee, corporate governance and consciousness and the morality of the stake holders play a vital role to control earnings management.

Sadeep (2016) presented a paper on the earnings management motivation: Accrual accounting vs. cash accounting, and opined that the accrual basis of accounting has always found favour amongst corporate practitioners of earnings management [18]. There have been extensive studies on earnings management, focusing on earnings hazards. The paper contributed to the literature by showing market inclination to accrual basis of accounting as motivated by a desire for earnings management. It analyzed the sample units' performance in regard to accrual-indicators vs. cash-indicators and their pervasiveness on stock pricing in India. In India, the corporate ownership model is the Promoter Dominated Shareholders Model (PDSHM) which makes this study unique in highlighting earnings management motivation. The units showed a market preference for accrual numbers and motivation for earnings management as clear in their stock pricing behavior. It was the hope of the researcher that the study improves investors' perception of the reliability of a firm's performance, as measured by earnings. It is of use to the users of financial accounting and corporate finance globally for rationalizing the motivation behind earnings manipulation by the management.

Abbadi, Hijazi, and Al-Rahahleh (2016) worked on corporate governance quality and earnings management: evidence from Jordan [9]. The paper investigated the effect of corporate governance quality on earnings management in Jordan. Using a panel data set of all industrial and service firms listed on Amman Stock Exchange (ASE) during the period 2009-2013, the paper provided evidence that earnings management is affected negatively by corporate governance quality. In particular; the results show that earnings management is affected negatively by overall categories of governance index represented by board of director, board meeting, Audit and nomination and compensation committee. Furthermore, results suggest that corporate governance quality has increased overtime. Thus, its ability to constrain earnings management has also increased. It is recommended to industrial and service companies to boost their compliance with corporate governance code to improve the integrity and reliability of financial reports. The paper filled a gap in the literature by providing evidence about the effect of corporate governance quality on earnings management in Jordan as an emerging economy.

Zhu and $\mathrm{Lu}$ (n.d.) reported on earnings management through real activities manipulation before mergers and acquisitions [19]. The study examined whether or not managers manipulate real activities to inflate their firms' market values before mergers and acquisitions (M\&As). The authors found that some managers do indeed initiate activities designed to boost their firms' market values prior to M\&As, specifically, relatively overvalued bidders conduct earnings manipulation through real activities before the mergers and acquisitions. The results suggested that discounted price that can increase sales temporarily and overproduction that can lower cost of goods sold reported are activities that executive employ to increase firm values prior to M\&As. Further analysis reveals that firm size also influences earnings via real activities manipulations.

Dani, Magro and Klann (2017) worked on earnings management through real activities: review of the existing literature and suggestions for future investigations [20]. The study aimed to characterize the results of research earnings management through real activities (GRAR) as well as possible gaps for future researches. For that, a bibliometric research was carried out, with a descriptive purpose, a documental procedure and a quantitative approach, and it was applied the technique of content analysis and the analysis of social networks through UCINET software. Scientific articles were collected, all of them published in international accounting journals of the area available in Scopus database. The seminal study of Roychowdhury (2006) on GRAR was the base of which a sample of 50 highest numbers of publications on GRAR with a greater significance from the Journal of Business Finance \& Accounting, although the production related to the theme has not evolved in a period of six consecutive years [21]. It was also observed that among those 50 publications, 27 were conducted in the United States, and 22 of them presented no theory in theoretical construction. Nevertheless, it was observed that the Agency Theory was the most frequent used theory among the other ones in publications.

Hashim, Salleh, and Ariff (2013) carried out a study on the underlying motives for earnings management: directors' perspective [13]. The paper provided evidence on the motives for directors to manage earnings. Adapting theory of 
reasoned actions, we examine three different motives (i.e. altruistic, speculative, and pressure from affiliated parties) for directors to manage earnings. It was found that the primary motive for directors to be involved in earnings management activity is derived from altruistic motivation, which referred to the motive that involves concern about the benefits of company. Directors work hard to meet market expectations and are more concerned about their company's reputation rather than their own personal benefits.

Regarding the application of GRAR metric, it was found that only 11 publications used the isolated model of actual activities [21]. In contrast, 39 publications applied together GRAR and models based on accruals. In view of these results, it is assumed that the theme and the model proposed by Roychowdhury (2006) have not yet been disseminated by the researchers, and so little has been consolidated in the literature of the area since the related publications are not constant. However, there was a considerable evolution in the period of 2014 and 2015, demonstrating an interest in the application of this metric, which in turn tends to be legitimized by researchers of the area, as well as other metrics of quality of previous accounting information. Finally, the study contributes to the development, expansion and identification of research-related gaps in national and international literature, providing insights for a new research, which may use variables and theories from a different perspective.

Roychowdhury (2006) studied earnings management through real activities manipulation [21]. The evidence was consistent with managers manipulating real activities to avoid reporting annual losses. Specifically, the researcher found evidence suggesting price discounts to temporarily increase sales, overproduction to report lower cost of goods sold, and reduction of discretionary expenditures to improve reported margins. Cross-sectional analysis revealed that these activities are less prevalent in the presence of sophisticated investors. Other factors that influence real activities manipulation include industry membership, the stock of inventories and receivables, and incentives to meet zero earnings. There is also some, though less robust, evidence of real activities manipulation to meet annual analyst forecasts.

Kothari, Mizik and Roychowdhury (2012) assessed the role of both accruals manipulation (AM) and real activities manipulation (RAM) in inducing overvaluation at the time of a seasoned equity offering (SEO) [22]. Our results reveal that earnings management is most closely and predictably linked with post-SEO stock market under-performance when it is driven by RAM. The results suggest that overvaluation at the time of the SEO is more likely when managers actively engage in more opaque channels to overstate earnings; accordingly managers exhibit a greater propensity to engage in RAM at the time of SEOs, even though RAM is more costly in the long run.. Thus, the focus in prior research on examining the influence of abnormal accruals on SEO overvaluation appears incomplete at best, since most existing studies do not consider the role of RAM in misleading investors at a time when firms are subject to substantial scrutiny.

Marcos dos Reis, Lamounier, and Bressan (2015) worked on the topic, avoiding reporting losses: an empirical study of earnings management via operating decisions [15]. The aim of this paper was to verify whether Brazilian companies listed on the BM \& FBOVESPA used earnings management via operating decisions, when faced with reporting unfavourable results, in order to avoid disclosing losses.

Using panel data covering years from 2008 to 2013 in estimated regression models, the paper focuses on three ways of manipulating financial results through operational decisions: by manipulating sales; by reducing selling, general and administrative expenses (SG\&A); and by increasing production to report lower costs of goods sold. The results show that the companies actually employed the use of SG\&A to avoid reporting losses, but did not manipulate sales or levels of production for such purposes. The evidence presented suggests that in Brazil managers are only able to manipulate operational activities by reducing operating expenses (SG\&A), probably due a lack of flexibility in the production process and the cash flow constraints faced by Brazilian companies. From a users' perspective, the paper found that companies do use earnings management via operating decisions to avoid disclosing losses to capital markets, which is consistent with the Prospect Theory.

Ruiz (2016) carried out a Literature review of earnings management: Who, why, when, how and what for? The author observed that accounting scandals such as Enron, Toshiba, Gowex or Pescanova are issues of special interest, given the impact that such fraudulent transactions have on society due, especially to earnings manipulation [1]. The aim of the paper was to review the literature concerning earnings management and the implications of the latter for stakeholders and firms. Using the Web of Science database, the author investigated the most cited papers on this topic. A classification of the causes that drive managers to manipulate earnings is presented and also explored the papers that show the trade-off faced by managers among the two techniques usually recognized in the earnings management literature, real activity and accrual manipulation, and when they are normally used. One of the major implications of earnings management is the deterioration of information quality in the financial statements, which could mislead stakeholders' decisions.

Marai and Pavlovi (2013) assessed earnings management and financial reporting fraud as key features for distinguishing [3]. According to the authors, major issue central to accountings research is the extent to which management is allowed to manage reported earnings, as well as the extent to which it becomes financial fraud. The paper discussed earnings management and financial reporting fraud, frameworks that existing literature offered to distinguish between them, how they in some cases overlap and the reasons that make the only relaying on accounting standards and also how management intent are not enough factors to provide clear differentiation between both.

Jordan and Clark (2015) attempted to unveil the question, 
“Do New CEOs Practice Big Bath Earnings Management via Goodwill Impairments?" using a research conducted during SFAS 142's adoption year (2002) [23]. Shortly thereafter the study indicated new CEOs exhibited big bath behavior by impairing goodwill early in their tenure. A new CEO could blame the impairment on prior management while also paving the way for enhanced future profitability. However, several studies indicate that various types of earnings management declined precipitously in recent years. The authors re-examined the propensity of new CEOs to take big baths relative to goodwill impairments and find no evidence of this manipulative reporting. It was rather found that, goodwill impairments by new CEOs seem to be justified based on their firms' deteriorating performance over time.

Cuzdriorean (2013) studied the most recent findings in earnings management area: Interesting insights from traditionally top 5 leading accounting journals [24]. A metaanalysis was conducted over the last 5 years comprising traditionally top 5 leading accounting research. The paper had an overview on emerging research and identified both framework papers that attracted significant attention and leading scholars in the field. The earnings management area exhibits considerable momentum, found largely driven by North American scholars focused research groups. The main goal of the paper was to offer a thoroughly understanding of what literature has achieved so far and to identify further research trends that scholars can use. To that extent, it is believed that this present study can, not only guide researchers, but also given the economic implications of the earnings management activities, the audience can comprise as well practitioners, accounting regulators or managers. Conclusions have been developed based on the sample assessed during the study.

According to Dela and Aeron (2015), Accounting inevitably involves making choices-tradeoffs, decisions between available alternatives [25]. The authors carried out a study on Earnings Management choice: An empirical study on the impact of earnings management on stock returns. This study focused on an accounting choice, specifically earnings management strategies along with their corresponding economic consequences. Prior studies have already provided evidence that firms make choices between two earnings management strategies-accounting-based and real activitiesbased and these strategies are being used as substitutes depending upon the relative costs involved. The focus of this study rests on how does a particular earnings management strategy choice (e.g. accounting-based, real activities-based, or both) affect capital market incentives for firms. The authors were of the view that in order to fully explain or capture the 'true' economic consequence of earnings management, it should not be dealt in isolation-considering only one strategy at a time, when in fact both can be used simultaneously.

Second, the increasing use of accounting information by investors and financial analysts to aid in valuing stocks creates an incentive for managers to manipulate earnings to influence stock performance. It is therefore interesting how capital markets respond to evidences of earnings management. The results of the study suggest that earnings management does not significantly affect short-term stock returns. It appears that incentives around earnings management are already well understood by market participants and thus, do not respond to evidences of earnings management. Furthermore, it also appears that investors are able to "see through" financial information and thus, are able to manage their expectations in the presence of earnings management.

Florio and Leoni (n.d.) carried out a study on earnings management (Italian convergence towards US) [26]. Facing the current convergence of Italia accounting research towards American accounting research, with specific reference to the stream of earnings management, the present paper aims at verifying if this convergence can be read as such institutional homogenization theorized in new institutional sociology [26]. Since accounting research can be viewed as an organizational field, immersed in the institutional setting of universities, the paper analyses the homogenization path of Italian EM research towards American one and detects the isomorphic mechanisms that drove such homogenization. To achieve the aims, the paper developed an historical comparison to highlight differences and similarities in the evolution of Italian and American EM research, according to international comparative accounting history. Such a comparison allowed the detection of those coercive, mimetic and normative pressures that drive the convergence of Italian EM research towards the dominating American EM research.

Cardoso, Martinez and Teixeir (2014) worked on Free Cash Flow and Earnings Management in Brazil: The Negative Side of Financial Slack [27]. The article investigates whether Brazilian firms with excess free cash flow (FCF) and low growth perspectives [28], when there is excess FCF, accompanied by limited growth perspectives, managers have incentives to camouflage the impact of investments in projects with negative net present value (NPV) by presenting inflated profits. The study includes firms listed on the BMF \& Bovespa in the period from 2008 to 2012. Discretionary accruals (DA) were estimated by the modified Jones model and then the relationship between FCF and DA was ascertained by multiple regressions. The results indicate that firms with low growth perspectives and excess FCF are more likely to manage earnings to increase profits. Shareholding concentration and adoption of IFRS moderate this relationship (FCF $x$ DA), i.e., in practical terms they restrict the propensity to engage in this type of earnings management. This study is relevant by identifying a tendency to manage earnings. Regulators and investors should pay particular attention to the accounting results disclosed in the presence of excess free cash flow and low growth perspectives.

Ghozali, Harto and Yuyetta (2018) researched on free cash flow, investment inefficiency, and earnings management [29]. The study was aimed at testing investment inefficiency of fixed assets in mediating the relationship between free cash flow and earnings management and to test the controlling 
shareholders in moderating the relationship between free cash flow and fixed assets investment inefficiency. The research problem proposed in this study is whether the use of free cash flow for the investment inefficiency of fixed assets is able to ultimately improve the managerial performance. The research investigated new empirical evidence related to management earnings practices caused by free cash flow fixed assets investment inefficiency. The study was conducted on all the manufacturing firms listed on the Indonesia stock exchange from 2010 to 2015. The data used are secondary data in the form of the firms' financial statements. Using purposive sampling, 314 units were analyzed from 69 manufacturing firms. The estimation of the path model was completed using Structural Equation Modeling (SEM) by Warp PLS program version 5.0. The results showed that free cash flow is positively related to earnings management. Fixed assets investment inefficiency is able to mediate the relationship between free cash flow and earnings management.

Osma, Grande-Herrera, and Vázquez (2017) worked on the role of independent directors on earnings management: Evidence from individual incentives, the role of independent directors on earnings management [30]. The authors presumed that independent directors' behavior hinges critically on their individual incentives. Using a large US sample for the period 1997 to 2013, the study constructed a measure of within-board heterogeneity among independent directors' incentives that is exogenous to a single firm's choices. Using this measure, it was found that individual incentives influence boards of directors' ability to constrain earnings management. In particular, it was shown that boards composed of independent directors with greater individual incentives lower real earnings management and increase informative accrual-based earnings management. Moreover, it was also believed to have provided an evidence of individual incentives influencing the firm information environment. The evidences highlight the importance of independent directors' individual incentives to carry out their fiduciary duty to monitor the financial reporting process.

Huang, Roychowdhury and Sletten (2017) tried to answer the question; does litigation encourage or deter real earnings management? The authors examined whether litigation risk encourages or deters real earnings management (REM) [31]. On the one hand, the literature argues that litigation risk restricts opportunism in voluntary disclosure and financial reporting choices. This is an encouragement to REM, as managers seek to substitute strategic disclosure and reporting with more opaque and difficult-to-detect earnings management via real actions.

On the other hand, REM's more negative implications for future stock price and operating performance documented in the literature suggest that shareholders should be motivated to identify and litigate instances of REM upon observing negative outcomes. This ex-post settling-up opportunity for shareholders can ex ante deter managers from engaging in REM. The authors conducted difference-in-difference tests centered on an unanticipated court ruling that reduced shareholders' ability to initiate class action lawsuits against firms headquartered in the Ninth Circuit. The researchers observed significant increases in REM following the ruling for Ninth Circuit firms relative to other firms. Further, these increases are more pronounced when managers are more entrenched and when firms have lower institutional ownership. The study concluded that the threat of litigation deters REM, especially when other mechanisms such as corporate governance and monitoring are weaker.

Badertscher, Phillips, Pincus and Rego (2009) researched into evidence on motivations for downward earnings management [32]. The authors analyzed a set of firms that restated earnings upward because of accounting irregularities and thus presumably had managed earnings downward. The results were consistent with the restatement sample firms having managed earnings downward in their original financial statements to create cookie jar reserves, to depress share prices prior to corporate and insider stock purchases, and to minimize political costs. There was no evidence these firms managed earnings downward to reduce income taxes, which is consistent with tax-motivated downward earnings management being accomplished via real transactions that typically do not give rise to accounting irregularities. The research estimate that taxable firms (i.e., profitable restatement sample firms without NOL carry forwards) left an average of 23 cents per dollar of pre-tax managed earnings on the table by engaging in book-tax non-conforming downward earnings management. The forgone tax savings represent a lower bound on the incremental costs associated with real transactions management.

Wang and D'Souza (2006) researched about evidence on motivations for downward earnings management [33]. The paper attempted to document the effects of accounting flexibility on managers' propensity to cut $R \& D$ expenditures. Using Barton and Simko's (2002) NOA/Sales variable as a proxy for accounting flexibility, it was found that managers are more (less) likely to cut R\&D when accounting flexibility is low (high), and that managers prefer the use of accrual to real earnings management given ample accounting flexibility [34]. The results were consistent with theoretical papers that posit substitution effects between accounting and real earnings management choices, with managers being more likely to cut R\&D when the marginal costs of accounting manipulations were low relative to real earnings manipulations.

Qiang (2013) worked on earnings management in small profit firms during financial crisis of 2008-2009 [35]. This paper examines empirically the managerial earnings management practices undertaken by small profits firms, and seeks whether these practices changed during the recent global financial crisis. Previous studies on small but positive earnings are normally in whether earnings management causes the discontinuity around zero in earnings distribution. There few studies combined discontinuity around zero with different macroeconomic conditions. The association between earnings management and small profit firms is investigated by three measures. First, earnings distribution of 
scaled earnings by lagged market value in different scaled earnings level during financial crisis is portrayed. Second, distribution of accumulated discretionary accruals which is the proxy for earnings management in different scaled earnings level is exhibited. Third, based on the qualified firm-year observations, discretionary accruals regressed on several earnings management controlling variables are tested.

Due to the limited number of qualified firm-year observations, two measures of small profit firms are used. The sample is selected from all listed firms in United States. Financial crisis period was confined in Year 2008 and 2009 when the stock price was in the bottom in recent decades. In these two years, the incentives from capital markets are restricted in the low level. Without considering financial crisis, there is income-increasing earnings management in small profit firms which is consistent with previous studies.

After considering financial crisis, the practices of earnings management is changed to income-decreasing, which provides the direct evidence on that the constitution of small profits firms are those ex-ante profit firms during the crisis and also provides the indirect evidence on that the constitution of small profits firms are small losses or losses firms in other periods. Both earnings distribution and accumulated discretionary accruals in financial crisis have the same consequence. The paper shows profit firms employ income-decreasing earnings management during the bad economic situation. The good financial performance from these firms in the post-crisis period need to be questioned whether the business actually revived.

Joosten (2012) citing Zang (2012) examined the extent to which the relative costs of real earnings management and accrual-based earnings management affect the trade-off between both strategies to manage earnings [36]. In contrast to Zang (2012), this study focused on European listed firms [37]. Consequently, investor protection is added as substitute for Sox. Furthermore, since Zang's (2012) proxy for financial distress, the Z-score, is intertwined with earnings management, this study rather uses cash flow-to-total debts to proxy for financial distress. The results show that European listed firms use real earnings management and accrual-based earnings management as substitutes to manage earnings downwards.

Furthermore, it is evident, in line with Zang (2012) explained that the substitutive trade-off is a function of the relative costs if firms face constraints that are associated with real earnings management. Firms which experience financial distress and higher industry competition have higher levels of accrual manipulation as both constrain real activities manipulation. Higher tax rates, however, do not constrain the use of real earnings management, but rather increase its use. However, in contrast to Zang (2012), it was less evident that the substitutive trade-off is a function of the relative costs if firms face constraints that are associated with accrual manipulation [37]. Whereas mixed evidence is acquired that investor protection increases real earnings management, accounting flexibility decreases real earnings management. Regarding downwards earnings management, this study reveals that accrual manipulation substitutes real earnings management if firms face financial distress and industry competition.

According to Roman (2009), "Earnings management occurs when firm management has the opportunity to make accounting decisions that change reported income and exploit those opportunities" [38]. The author also stated that accounting for business operations requires judgment and estimates. For example, one can't measure revenue without estimating when customers will pay, how many will not pay, how many will return goods for refund and costs to the seller for fulfillment of warranty or maintenance promises.

Goel (2016) carried out a study on the earnings management motivation: Accrual accounting vs. cash accounting [39]. The researcher suggested that the accrual basis of accounting has always found favour amongst corporate practitioners of earnings management. There have been extensive studies on earnings management, focusing on earnings hazards. The paper contributes to the literature by showing market inclination to accrual basis of accounting as motivated by a desire for earnings management. It analyzed the sample units' performance in regard to accrual-indicators vs. cash-indicators and their pervasiveness on stock pricing in India. In India, the corporate ownership model is the Promoter Dominated Shareholders Model (PDSHM) which makes this study unique in highlighting earnings management motivation. The units show a market preference for accrual numbers and motivation for earnings management as clear in their stock pricing behavior. It was the expectation and hope of the researcher that the study improves investors' perception of the reliability of a firm's performance, as measured by earnings. It is of use to the users of financial accounting and corporate finance globally for rationalizing the motivation behind earnings manipulation by the management.

\subsection{Summary of Literature Review}

The views of the various researchers surrounding earnings management and its application are vast and wide in application. There is no doubt that earnings management must have come a long way with universal application and practice. Almost all the studies reviewed have pointed to the fact that managers are drawn into the use of earnings management and are conversant with it one way or the other. To the managers, it is a means of escaping from the dangers of basing the business on economic reality only.

There is substantial evidence that many executives engage in earnings management. One means of managing earnings from the available literatures is by manipulation of accruals with no direct cash flow consequences, hereafter referred to as accrual manipulation. Examples include underprovisioning for bad debt expenses and delaying asset writeoffs. Managers also have incentives to manipulate real activities during the year to meet certain earnings targets. Real activities manipulation affects cash flows and in some cases, accruals. Much of the current research on earnings management focuses on detecting abnormal accruals. Studies 
that directly examine earnings management through real activities have concentrated mostly on investment activities, such as reductions in expenditures on research and development.

Economies and business profits may not be truly as reported in the statements of accounts. There has to be a balance between the reality and what can make businesses to survive hence earnings management. There is necessity to uphold this practice as long as it is generally accepted and keeps businesses afloat in the face of perceived dangers. Since real activities management is expected to be costlier for the firm, it may be natural to expect that managers attempt to accomplish earnings management via accruals before they engage in opportunistic real activities. This paper suggests that at times of heightened scrutiny, managers can exhibit a preference for real activities manipulation strategies if they wish to inflate earnings, because such strategies have a higher probability of escaping detection.

\section{Methodology}

\subsection{Research Design}

The study adopted the historical or rather the ex-post facto research design. The essence is to search for data that are recorded over a period of time and which exists in the administrative records and accounts of the selected firms. Such records are considered adequate, representative and acceptable in the process of carrying out a study.

\subsection{Source of Data}

The data used for this analysis have been obtained from the published reports and accounts of the sampled firms (for the relevant years. In order words, the data are secondary in nature.

\subsection{Population}

The population of study is the number of consumer goods firms listed in the Nigeria Stock Market (NSM). They are 20 in all as shown in the appendix.

\subsection{Sample Determination}

The companies used for the study have been chosen using purposive sampling technique. This permitted that the researcher could use discretion to arrive at such number of sample that conform to the specifications of the study and sometimes for convenience sake. The three firms selected for this purpose are Nigerian Breweries plc, Guinness Nig. Plc and Dangote Flour Mills Plc.

\subsection{Model Adoption}

The model for the study is expressed as follows:

$$
\begin{gathered}
\mathrm{AS}=f(\text { EARNMGT }) \\
\mathrm{EQT}=f(\text { EARNMGT }) \\
\mathrm{LIAB}=f(\text { EARNMGT })
\end{gathered}
$$

\subsection{Description of the Variables}

EARNMGT means earnings management (independent Variable)

AS represents Assets (dependent variable 1)

EQT represents Equity (dependent variable 2)

LIAB represents Liability (dependent variable 3)

\section{Presentation and Analysis of Data}

\subsection{Presentation of Data}

Table 1. Pooled data of Nigerian Breweries plc, Guinness Nig. plc and Dangote Four Mills plc.

\begin{tabular}{lllll}
\hline Year & Total assets & Equity & $\begin{array}{l}\text { Total } \\
\text { liability }\end{array}$ & $\begin{array}{l}\text { Profit for } \\
\text { the year }\end{array}$ \\
\hline 2009 & $195,010,139$ & $104,844,376$ & $107,386,712$ & $46,811,141$ \\
2010 & $225,315,585$ & $110,860,435$ & $56,659,605$ & $47,821,725$ \\
2011 & $349,358,581$ & $144,601,224$ & $204,757,357$ & $57,149,451$ \\
2012 & $415,967,900$ & $156,514,869$ & $252,492,897$ & $49,575,790$ \\
2013 & $433,561,353$ & $176,632,121$ & $263,193,095$ & $50,463,427$ \\
2014 & $535,568,800$ & $231,019,070$ & $304,548,840$ & $47,934,431$ \\
2015 & $525,298,184$ & $220,571,036$ & $304,727,343$ & $31,756,623$ \\
2016 & $581,237,647$ & $237,261,424$ & $344,977,223$ & $20,491,247$ \\
2017 & $658,106,696$ & $260,581,818$ & $397,524,519$ & $47,490,734$ \\
2018 & $541,517,837$ & $291,118,804$ & $374,775,283$ & $29,433,671$ \\
\hline
\end{tabular}

Source: Compilation by researcher, 2019 based on Appendix

\subsection{Analysis of Data}

\subsubsection{Analysis on Objective 1}

Restatement of the hypothesis

$\mathrm{H}_{1}$ : Earnings Management has no significant effect on Total Assets of Consumer Goods companies in Nigeria

Decision Rule: Reject $\mathrm{H}_{1}$ if $\mathrm{p}$-value $<0.05$, otherwise accept.

Table 2. Correlation Analysis on Total Assets and Earnings Management.

\begin{tabular}{lllll}
\hline Model Summary & & & & \\
\hline Model & R & R Square & Adjusted R Square & Std. Error of the Estimate \\
\hline 1 & $.475^{\text {a }}$ & .226 & .129 & 142161541.983 \\
\hline
\end{tabular}

a. Predictors: (Constant), PFY

The analysis in table 2 shows that total assets has a positive but low or weak correlation (i.e. $r=0.476$ ) with Earnings Management (profit for the period) and EM was only able to have 22.6\% impact on assets for the year (PFY). 
Table 3. Analysis of Variance on Total Assets and Earnings Management.

\begin{tabular}{llllll}
\hline ANOVA $^{\mathbf{a}}$ & & & & & \\
\hline Model & & Sum of Squares & Df & Mean Square & F \\
\hline \multirow{2}{*}{1} & Regression & 47127311917686664.000 & 1 & 47127311917686664.000 & 2.332 \\
& Residual & 161679232152891616.000 & 8 & 20209904019111452.000 & $.165^{\mathrm{b}}$ \\
& Total & 208806544070578272.000 & 9 & & \\
\hline
\end{tabular}

a. Dependent Variable: TOTASS

b. Predictors: (Constant), PFY

The analysis in table 3 shows that $\mathrm{p}$-value $=0.0 .165$. Since $\mathrm{p}$-value $>0.05$, we accept $\mathrm{H}_{1}$ and conclude that Earnings Management has no significant effect on Total Assets of consumer goods firms in Nigeria.

Table 4. Regression Analysis on Total Assets and Earnings Management.

\begin{tabular}{|c|c|c|c|c|c|c|}
\hline \multicolumn{7}{|c|}{ Coefficients $^{\mathrm{a}}$} \\
\hline \multirow{2}{*}{ Model } & & \multicolumn{2}{|c|}{ Unstandardized Coefficients } & \multirow{2}{*}{$\begin{array}{l}\text { Standardized Coefficients } \\
\text { Beta }\end{array}$} & \multirow{2}{*}{$\mathbf{T}$} & \multirow{2}{*}{ P-value } \\
\hline & & B & Std. Error & & & \\
\hline \multirow{2}{*}{1} & (Constant) & 715071210.661 & 181787503.711 & & 3.934 & .004 \\
\hline & PFY & -6.271 & 4.107 & -.475 & -1.527 & .165 \\
\hline
\end{tabular}

a. Dependent Variable: TOTASS

The model for this relationship is spelt out as follows:

$$
\text { AS }=715071210.661-6.271(\text { EARNMGT) }+4.107
$$

This means that Earnings Management contributed an

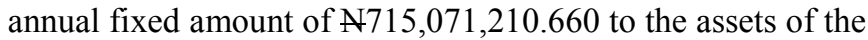
industry. During the period, it was found that earnings management also diminished marginally at the rate of 6.271 per annum during the period.

\subsubsection{Analysis on Objective 2}

Restatement of the Hypothesis

$\mathrm{H}_{2}$ : Earnings Management has no significant impact on Equity of Consumer Goods firms in Nigeria.

Decision Rule: Reject $\mathrm{H}_{2}$ if $\mathrm{p}$-value $<0.05$, otherwise accept.

Table 5. Correlation Analysis on Equity and Earnings Management.

\begin{tabular}{lllll}
\hline Model Summary & & & & \\
\hline Model & R & R Square & Adjusted R Square & Std. Error of the Estimate \\
\hline 1 & $.591^{\mathrm{a}}$ & .349 & .268 & 54731328.878 \\
\hline
\end{tabular}

a. Predictors: (Constant), PFY

Table 5 shows the correlation between Equity and Profit for the Year of Consumer Goods firms in Nigeria. The analysis shows that there is a positive and high correlation between Equity and Profit for the Year $(\mathrm{r}=0.591$ or 59.1 percent). The analysis also indicates that the coefficient of determination (R2) is 0.349 or 34.9 percent. It implies that Earnings Management was able to determine the variations in Equity up to 34.9 percent only. In order words, EM explained 34.9 percent of the change in firms' equity which may be considered as grossly inadequate.

Table 6. Analysis of Variance between Equity and Earnings Management.

\begin{tabular}{|c|c|c|c|c|c|c|}
\hline \multicolumn{7}{|c|}{ ANOVA $^{a}$} \\
\hline Model & & Sum of Squares & Df & Mean Square & $\mathbf{F}$ & P-value. \\
\hline \multirow{3}{*}{1} & Regression & 12853372103079280.000 & 1 & 12853372103079280.000 & 4.291 & $.072^{\mathrm{b}}$ \\
\hline & Residual & 23964146886064680.000 & 8 & 2995518360758085.000 & & \\
\hline & Total & 36817518989143960.000 & 9 & & & \\
\hline
\end{tabular}

a. Dependent Variable: EQTY

b. Predictors: (Constant), PFY

The ANOVA in table 6 shows that $\mathrm{p}$-value $=0.072$, Since $0.072>0.05$, we do not reject $\mathrm{H}_{2}$ but conclude that Earnings
Management has no significant effect on equity of consumer goods firms in Nigeria.

Table 7. Regression Analysis on Equity and Earnings Management.

\begin{tabular}{|c|c|c|c|c|c|c|}
\hline \multicolumn{7}{|c|}{ Coefficients $^{\mathrm{a}}$} \\
\hline \multirow{2}{*}{ Model } & & \multicolumn{2}{|c|}{ Unstandardized Coefficients } & \multirow{2}{*}{$\begin{array}{l}\text { Standardized Coefficients } \\
\text { Beta }\end{array}$} & \multirow{2}{*}{$\mathbf{T}$} & \multirow{2}{*}{ P-value } \\
\hline & & B & Std. Error & & & \\
\hline \multirow{2}{*}{1} & (Constant) & 333871704.569 & 69987083.094 & & 4.770 & .001 \\
\hline & PFY & -3.275 & 1.581 & -.591 & -2.071 & .072 \\
\hline
\end{tabular}

a. Dependent Variable: EQTY 
The model for this relationship can simply be stated as follows:

$$
\mathrm{EQT}=333871704.569-3.275(\text { EARNMGT })+1.581
$$

This implies that EM contributed a constant annual amount of $\mathrm{N} 333,871,704.568$ to changes in Equity during the period. However, there was also a marginal decrease in the contribution of EM to EQT during the period. Perhaps that was responsible for the low level of significance in EQT. The error of estimation is 1.581 .

\subsubsection{Analysis on Objective 3}

Restatement of the Hypothesis

$\mathrm{H}_{3}$ : Earnings Management has no significant impact on Total Liability of Consumer Goods firms in Nigeria.

Decision Rule: Reject $\mathrm{H}_{3}$ if $\mathrm{p}$-value $<0.05$, otherwise accept

Table 8. Correlation Analysis on Total Liability and Earnings Management.

\begin{tabular}{llll}
\hline Model Summary & & \\
\hline Model & R & R Square & Adjusted R Square \\
\hline 1 & $.477^{\mathrm{a}}$ & .228 & .131 \\
\hline
\end{tabular}

a. Predictors: (Constant), PFY

In table 8 we find out that the coefficient of correlation, $\mathrm{r}=$ 0.477 while the coefficient of determination $\mathrm{R}^{2}=0.228$. This means that there is a weak correlation between total liability and earnings management of consumer goods firms in Nigeria. The outcome also implies that EM was only able to determine or explain 22.8 percent of the variations in total liability during the period. The unexplained variation is estimated to be 77.2 percent and that is very large and of concern.

Table 9. Analysis of Variance between Liability and Earnings Management.

\begin{tabular}{llllll}
\hline ANOVA $^{\mathbf{a}}$ & & & & \\
\hline Model & & Sum of Squares & Df & Mean Square & P-value \\
\hline \multirow{3}{*}{1} & Regression & 25272375910892344.000 & 1 & 25272375910892344.000 \\
& Residual & 85764485252062144.000 & 8 & 10720560656507768.000 \\
& Total & 111036861162954496.000 & 9 & & $.163^{\text {b }}$ \\
\end{tabular}

a. Dependent Variable: TOTLIAB

b. Predictors: (Constant), PFY

Table 9 reveals that $\mathrm{p}$-value $=0.163$. Since $0.163>0.05$, we do not reject $\mathrm{H}_{3}$, hence we conclude that EM has no significant impact on total liability of consumer goods firms in Nigeria.

Table 10. Regression Analysis on Total Liability and Earnings Management.

\begin{tabular}{llllll}
\hline \multicolumn{2}{l}{ Coefficients $^{\mathbf{a}}$} & & & \\
\multirow{2}{*}{ Model } & & \multicolumn{2}{l}{ Unstandardized Coefficients } & Standardized Coefficients & \multirow{2}{*}{ t } \\
\cline { 3 - 5 } & & B & Std. Error & Beta & 3.460 \\
\multirow{2}{*}{1} & (Constant) & 458075041.698 & 132400812.338 & & .009 \\
& PFY & -4.592 & 2.991 & -.477 & -1.535 \\
\hline
\end{tabular}

a. Dependent Variable: TOTLIAB

We can fit the coefficients in table 10 to the model and presented as follows:

TOTLIAB $=458,075,041.698-4.592($ EARNMGT $)+2.991$

It implies that EM contributed an annual constant value of N458,075,041.698 to total liability of the firms over the period. Similarly, there was a marginal annual decrease of 4.592 over the period. The constant contribution is significant while EM is not.

\section{Summary of Findings}

The findings from this study are summarized as follows:

1. Earnings Management does not have significant impact on Total Assets of consumer goods firms in Nigeria,

2. Earnings Management does not have significant impact on Equity of consumer goods firms in Nigeria.

3. Earnings Management does not have significant impact on Total Liabilities of consumer goods firms in Nigeria.

\subsection{Conclusion}

There is fulfillment in research effort whenever the desired results are achieved. The outcome of the study has been able to point to the desire of the researcher to determine the impact of earnings management on financial performance of consumer goods firms in Nigeria. The users of this information will not only find it satisfying but would be able to adopt in contemporary decision making whether in finance or management issues.

\subsection{Recommendations}

The study hereby recommends the following to interested 
users:

1. There should be conscious effort by management of consumer goods firms to improve the earnings management situation in order to impact on financial performance of the sector.

2. Management of consumer goods firms should emphasize the equity of firms as a means of widening ownership fund position and internal source of capital.

3. There must be re-assessment of the liabilities of such firms for proper positioning of financial performance of consumer goods firms in Nigeria.

\section{References}

[1] Ruiz, C. V. (2016). Literature review of earnings management: Who, why, when, how and what for? Finnish Business Review, online at http://urn.fi/urn:nbn:fi:jamk-issn-2341-9938-12, on July 22, 2018.

[2] Mulford C. W. \& Comiskey E. E. (2012). The financial numbers game, detecting creative accounting practices. New York: John Wiley and Sons Inc.

[3] Marai, A. \& Pavlovi, V. (2013). Earnings management vs financial reporting fraud - Key features for distinguishing, Economics and Organization, 10 (1), 39-47.

[4] Lev, B. (1989). On the usefulness of earnings and earnings research: Lessons and directions from two decades of empirical research, Journal of Accounting Research, 153-201.

[5] Goncharov, I. (2005). Earnings management and its determinants: closing gaps in empirical accounting research, Europeans University Studies, Alemanha.

[6] Kothari S. P. (2001). Capital markets research in accounting. Sloan School of Management, Massachusetts Institute of Technology, Cambridge.

[7] Warglien, M. \& Saccon, C. (2010). Earnings Management, Human Rationality, and Relative, Deprivation -- Some Critical Assessments, Dottorato di ricerca in Economia Aziendale Scuola di dottorato in Scuola Superiore in Economia, (A. A 2007/08 - 2010/11), Universita Ca'Foscari, Venezia, retrieved on July 27, 2017.

[8] Scott W. (2003). Financial Accounting Theory. Pearson Education. Toronto. Ontaro.

[9] Abbadi, S. S., Hijazi, Q. F. \& Al-Rahahleh, A. S. (2016). Corporate governance quality and earnings management: Evidence from Jordan, Australasian Accounting, Business and Finance Journal, 10 (2), 54-75. doi: 10.14453/aabfj.v10i2.4.

[10] Rosenzweig K., \& Fischer M. (1995). Is managing earnings ethically acceptable? Management Accounting, 75; 9, pp 31-34.

[11] Leuz, C., Nandab, D. \& Wysocki, P. D. (2003). Earnings Management and Investor Protection: An International Comparison, Journal of Financial Economics, 69, 505-527. http://dx.doi.org/10.1016/S0304-405X(03)00121-1, retrieved on July 29, 2018.

[12] Hijazi, Q. (2015). Unpublished master thesis, University of Jordan, Amman, Jordan.

[13] Hashim, A. H., Salleh, Z. \& Ariff, A. M. (2013). The underlying motives for earnings management: Directors Perspective, International Journal of Trade, Economics and Finance, 4 (5), 296- 299.

[14] Rahman, M., M., Moniruzzaman, M. \& Sharif, M. J. (2013). Techniques, motives and controls of earnings management, International Journal of Information Technology and Business Management, 11 (1), 22-34.

[15] Marcos dos Reis, E., Lamounier, W. M. \& Bressan, V. G. F. (2015). Avoiding reporting losses: An empirical study of earnings management via operating decisions, 26 (69), 247-26, DOI: $10.1590 / 1808-057 \times 201501070$.

[16] Kenton, W. (2019). What is financial performance? Available at $\mathrm{https}$ ://www.investopedia.com/terms/f/financialperformance.asp, retrieved on September 10, 2019.

[17] Barney, J. B. (1991). Firm Resources and Sustained Competitive Advantage. Journal of Management, 17, 99-120.

[18] Sandeep, G. (2016). The earnings management motivation: Accrual accounting vs. cash accounting, Australasian Accounting, Business and Finance Journal, 10 (3), 48-66, doi: 10.14453/aabfj.v10i3.4.

[19] Zhu, X. \& Lu, S. (n.d.). Earnings management through real activities manipulation before mergers and acquisitions, Journal of Finance and Accountancy, 1-6, retrieved on July 27, 2018.

[20] Dani, A. C., Magro, C. B. D. \& Klann, R. C. (2017). Earnings management through real activities: review of the existing literature and suggestions for future investigations, DOI: http://dx.doi.org/10.18028/2238-5320/ rgfc.v7n2p, 102-120.

[21] Roychowdhury, S. (2006). Earnings management through real activities manipulation, Journal of Accounting and Economics, $42,335-370$.

[22] Kothari, S. P., Mizik, N. \& Roychowdhury, S. (2012). Managing for the Moment: The Role of Real Activity versus Accruals Earnings Management in SEO Valuation, seminar held at Boston College, USA.

[23] Jordan, C. E \& Clark, S. J. (2015). Do new CEOs practice big bath earnings management via goodwill impairments? Journal of Accounting and Finance, 15 (7), 11-21.

[24] Cuzdriorean, D. D. (2013). Most recent findings in earnings management area: Interesting insights from traditionally top 5 leading accounting journals, Annales Universitatis Apulensis Series Oeconomica, 15 (2), 402-416.

[25] Dela, C. \& Aeson, L. C. (2015). Earnings Management Choice: An Empirical Study on the Impact of Earnings Management on Stock Returns, Presented at the DLSU Research Congress vol. 3, held at De La Salle University, Manila, Philippines March 2-4, 2015.

[26] Florio, C. \& Leoni, G. (n.d.). Earnings management research: Italian convergence towards US, 1-36.

[27] Cardoso, F. T., Martinez, A. L. \& Teixeir, A. J. C. (2014). Free Cash Flow and Earnings Management in Brazil: The Negative Side of Financial Slack, Global Journal of Management and Business Research: D Accounting and Auditing, 14 (1), 84-96.

[28] Jensen M. (1986). The agency costs of free cash flows, corporate finance and takeovers. American Economic Review $76,323-329$. 
[29] Ghozali, I., Harto, P. \& Yuyetta, E. N. A. (2018). Free cash flow, investment inefficiency, and earnings management: Evidence from manufacturing firms listed on the Indonesia Stock Exchange, Investment Management and Financial Innovations, 15 (11), 299-310.

[30] Osma, B. G., Grande-Herrera, C. \& Vázquez, A. B. (2017). The role of independent directors on earnings management: Evidence from individual incentives, 1-55.

[31] Huang, S., Roychowdhury, S. \& Sletten, E. (2017). Does Litigation Encourage or Deter Real Earnings Management? 142 .

[32] Badertscher, B., Phillips, J., Pincus, M., \& Rego, S. O. (2009). Evidence on Motivations for downward Earnings Management, retrieved on July 27, 2018.

[33] Wang, S. \& D'Souza, J. (2006). Earnings management: the effect of accounting flexibility on R\&D investment choices, Cornell University, Johnson School Research Paper Series \#33-06.

[34] Barton J \& Simko P (2002). The balance sheet as an earnings management constraint. The Accounting Review. 77. $10.2139 / \mathrm{ssrn} .320641$.

[35] Qiang, X. (2013). Earnings management in small profit firms during financial crisis of 2008- 2009, Master's Thesis Accounting, Oulu Business School, University of Oulu, retrieved on July 27, 2018.
[36] Joosten, C. (2012). Real earnings management and accrualbased earnings management as substitutes, Master thesis Department Accountancy Faculty of Economics and Business Studies Tilburg University.

[37] Zang, A. Y. (2012). Evidence on the trade-off between real activities manipulation and accrual- based earnings management, The Accounting Review, 87 (2), 675-703.

[38] Roman, L. W. (2009). Quality of Earnings and Earnings Management, Journal of AICPA, available at http://www.aicpa.org/ForThePublic/AuditCommitteeEffective ness/AuditCommitteeBrief/DownloadableDocuments/Audit Committee_Quality_of_Earnings.pdf, retrieved on July 27, 2019.

[39] Goel, S. (2016). The Earnings Management Motivation: Accrual Accounting vs. Cash Accounting, Australasian Accounting, Business and Finance Journal, 10 (3), 2016, 4866. doi: 10.14453/aabfj.v10i3.4.

[40] Cheng, Q, Lee, J. \& Shevlin, T. (2013). Internal governance and real earnings management, American Accounting Association Financial Accounting and Reporting Section Midyear Meeting 2013, January 11-13; University of Technology at Sydney Annual Accounting Conference 2013, February; American Accounting Association Annual Meeting 2013, August 3-7, 158. Research Collection School of Accountancy, available at: http://ink.library.smu.edu.sg/soa_research/1086, retrieved on July 25, 2018. 